\title{
Editorial
}

\section{International Organizations and Customary International Law}

\author{
Is the International Law Commission Taking International Organizations \\ Seriously?
}

\author{
Niels Blokker \\ Leiden University \\ n.m.blokker@law.leidenuniv.nl
}

\section{$1 \quad$ Introduction}

Customary international law is relevant for international organizations, at times even essential. International organizations may derive both rights and obligations from this source of international law. Early this year, a Dutch court recognized that North Atlantic Treaty Organization ('NATO') entities enjoy immunity from jurisdiction on the basis of customary international law, in a case involving a private claim of hundreds of millions of us dollars. ${ }^{1}$ It is

* Professor of International Institutional Law (Schermers Chair), Grotius Centre for International Legal Studies, Leiden University. I thank colleagues of the Grotius Centre and from the Board of Editors of this journal for their comments on a draft version of this editorial.

1 Supreme Site Services Gмвн and Orsv Allied Joint Force Command Headquarters Brunssum and Anor (Limburg District Court, Case No C/03/217614/HA ZA 16/130 (ECLI:NL:RBLIM:2017:1002), Judgment in the Ancillary Proceedings 8 February 2017). In this judgment, now under appeal, the Court followed Spaans v Iran-United States Claims Tribunal (Dutch Supreme Court, Case No 12627, Final Appeal Judgment 20 December 1985) (translation in (1987) 18 Netherlands Yearbook of International Law 357). Even though this is the view of Dutch courts, it should be mentioned that it is far from generally accepted that international organizations may enjoy immunity not only on the basis of treaties, but also on the basis of customary international

(C) NIELS BLOKKER, 2017 | DOI 10.1163/15723747-01401001

This is an open access article distributed under the terms of the Creative Commons Attribution-

Noncommercial 4.0 Unported (CC-BY-NC 4.0) License. http://creativecommons,org/licenses/by-nc/4,0/623 01:43:55PM 
also increasingly accepted that international organizations are bound by obligations under customary international law. ${ }^{2}$ Such obligations concern, for example, international human rights law and international humanitarian law. The practical relevance of this is clear if we ask whether United Nations ('UN') peacekeeping forces are fully bound by customary human rights and humanitarian law, knowing that it is unlikely that many international organizations will become parties to human rights and humanitarian law conventions in the near future. Therefore: customary international law is relevant for international organizations, at times even essential.

In 2012, the International Law Commission ('ILC') decided to include the topic 'Formation and evidence of customary international law' in its programme of work and appointed its member Michael Wood as Special Rapporteur for the topic. In 2013, it changed the title of the topic to 'Identification of customary international law'. The Special Rapporteur has prepared four reports during the last few years, and has actively promoted discussions on the topic. ${ }^{3}$ In 2016, the ILC adopted, at first reading, a set of 16 'draft conclusions on customary international law'. It will resume its work on this topic in 2018, with the intention of concluding it that year. So this is the time to react to the draft conclusions, and this is the time to address the question of whether the ILC has taken international organizations seriously in the provisional outcome of its work on this topic.

law; see Michael Wood, 'Do International Organizations Enjoy Immunity Under Customary International Law?' (2013) 10(2) International Organizations Law Review 287.

2 Kristina Daugirdas, 'How and Why International Law Binds International Organizations' (2016) 57(2) Harvard International Law Journal 325 (arguing, inter alia, that customary international law binds international organizations "as a default matter", "like states, Ios may contract around such default rules” (at 327)). See also August Reinisch, 'General Reflections on International Organizations Adapting to a Rapidly Changing World' (2015) 109 Proceedings of the Annual Meeting 283; August Reinisch, 'Sources of International Organizations' Law: Why Custom and General Principles are Crucial' in S. Besson and J. d'Aspremont (eds), The Oxford Handbook on the Sources of International Law (Oxford University Press, 2017) (forthcoming).

3 By contributing to conferences and by organizing informal meetings. See also his 2014 Jonathan J. Charney Distinguished Lecture in Public International Law, 'International Organizations and Customary International Law', published in (2015) 48 Vanderbilt Journal of Transnational Law 609.

4 Report International Law Commission on its Sixty-Eighth Session, un Doc. A/71/10 (19 August 2016), 76-117. 
In the past, the ILC has also considered the role of international organizations. This was the case when it prepared general rules on that other main source of international law, treaties. It initially considered preparing a convention containing general rules for treaties, irrespective of whether the parties would be states or international organizations. However, in the end it decided to separate treaties for states from treaties for international organizations. ${ }^{5}$ This resulted in the Vienna Convention on the Law of Treaties (1969), restricted to treaties concluded between states, and the Vienna Convention on the Law of Treaties between States and International Organizations or Between International Organizations (1986). At the same time, when comparing the text of these two Vienna Conventions, it is clear that the rules on treaties are almost completely similar. More recently, in its work on international responsibility, the ILC has also separated states and international organizations. After four decades of work it adopted the Articles on the Responsibility of States for Internationally Wrongful Acts in 2001. In the course of this work members discussed whether the articles should also cover the responsibility of international organizations, but this did not find much support. ${ }^{6}$ After having completed its work on state responsibility, the ILC put the topic of the responsibility of international organizations on its agenda. This was completed in 2011. While many of the Articles on the Responsibility of International Organizations (ARIO) are similar to those for states, there are some important differences. ${ }^{7}$ In contrast, in its current work on customary international law, the ILC has not decided to separate states and international organizations, but has prepared general conclusions about customary international law.

\subsection{A General Practice}

The draft conclusions as adopted in 2016 concern the way in which the existence and content of rules of customary international law are to be deter-

5 Catherine Brölmann, The Institutional Veil in Public International Law: International Organisations \& the Law of Treaties (Hart Publishing, 2007), in particular Chapter 8.

6 ILC member-and Second Special Rapporteur on State Responsibility-Roberto Ago took the view that it was "questionable whether such [international] organizations had the capacity to commit international wrongful acts", and that "international organizations were too recent a phenomenon and the question of a possible international responsibility by reason of alleged wrongful acts committed by such organizations was not suited to codification" ('Report by Mr Roberto Ago, Chairman of the Sub-Committee on State Responsibility' [1963] II Yearbook of the International Law Commission 229, 234).

7 See the contributions to the Forum on ARIO in (2012) 9 International Organizations Law Review $1-85$. 
mined (draft conclusion 1). When reading the 16 draft conclusions, it is clear that the ILC certainly sought to take into account the role of international organizations in the identification of customary international law. It recognizes the relevance of international organizations when ascertaining whether there is a general practice and an opinio iuris. This is particularly clear from draft conclusion 4 ('requirement of practice'). Of course, in paragraph 1 of this draft conclusion, the ILC states that this is "primarily" about the practice of States. However, the next question is whether and, if so, to what extent the practice of non-state actors is relevant for the identification of rules of customary international law. In practice, their role has assumed increasing importance in international relations and international law, as has been recognized in doctrine. In paragraphs 2 and 3 of draft conclusion 4 , the ILC distinguishes between international organizations and other actors. In paragraph 2, the ILC states, "[i]n certain cases, the practice of international organizations also contributes to the formation, or expression, of rules of customary international law". This is different for other actors: in paragraph 3, the ILC states that their conduct is not 'practice' that contributes to the formation, or expression, of rules of customary international law. Other actors' conduct may only be indirectly relevant, that is, when assessing the practice of States and international organizations. It is therefore clear that the ILC is recognizing the direct relevance of the practice of international organizations for the identification of customary international law. This is also true for a few of the more specific draft conclusions that follow. Draft conclusion 8 ("the practice must be general") is stated in general terms, covering both State practice and the practice of international organizations (hereinafter the latter will be referred to as 'Io practice'), and the same is partly true for draft conclusion 6 ("forms of practice").

However, some of the other draft conclusions about 'a general practice' are not phrased in general terms. Here the ILC is exclusively and explicitly focusing on State practice only, sending the message that the same does not apply to international organizations. Draft conclusion 5 ("Conduct of the State as State practice") stipulates: "State practice consists of conduct of the State, whether in the exercise of its executive, legislative, judicial or other functions". There is no 'sister conclusion', or conclusion 5 bis, called "Conduct of an international organization as Io practice", even though some international organizations (such as the European Union and some other regional integration international organizations) also exercise executive, legislative, judicial, or other functions.

Draft conclusion 6 seems to be more general. Its title is "forms of practice" (not: 'forms of State practice'). However, while paragraphs 1 and 3 are about practice in general (assumingly covering both the practice of States and that of 
international organizations), paragraph 2 (and the commentary to paragraph 2 ) exclusively concerns forms of State practice-as if international organizations never act through "diplomatic acts and correspondence" and never carry out any operational conduct "on the ground".

Next, draft conclusion 7 ("Assessing a State's practice") is again exclusively about State practice. It is not clear why. Is the practice of international organizations not "to be assessed as a whole"? When the practice of an international organization varies, is it not true that "the weight to be given to that practice may be reduced"?

Therefore, in my view, the ILC is ambivalent in these conclusions regarding the first constituent element of customary international law, general practice. On the one hand, it recognizes that Io practice may contribute to the formation, or expression, of rules of customary international law. But on the other hand, draft conclusions 4 to 8 do not fully reflect this, and parts of these draft conclusions cover only State practice.

The ILC has tried to deal with this criticism by including the following sentence in comment (3) to draft conclusion 4: "References in the draft conclusions and commentaries to the practice of States should thus be read as including, in those cases where it is relevant, the practice of international organizations". But this single cosmetic sentence, hidden in the commentary, cannot remedy the deficiency of ambivalence in the main text of the draft conclusions themselves. If the ILC would really fully appreciate Io practice, if it would really recognize that this practice may contribute to the formation, or expression, of rules of customary international law, why did it not phrase the draft conclusions in more general terms, or simply speak about 'States and international organizations'? This is certainly not to say that Io practice is as important as that of States. But it may be relevant in certain fields, including in the examples described above of draft conclusions that, as currently presented, nevertheless exclusively refer to State practice.

\subsection{Opinio Iuris}

There is a similar ambivalence in the conclusions about the second element, opinio iuris. Draft conclusion 9 ("Requirement of acceptance as law (opinio iuris)") is of a general nature and seems to cover both opinio iuris of States and of international organizations. However, draft conclusion 10 ("Forms of evidence of acceptance as law (opinio iuris)") in its paragraph 2 seems to deal mostly or only with forms of evidence of opinio iuris from States, and paragraph 3 only refers to States. The reluctance of the ILC to accept a serious role for international organizations in its two draft conclusions about opinio iuris is also clear from the commentary to these draft conclusions. Here we do not even find a sentence such as the cosmetic one in the commentary to practice 
(something like 'references to the opinio iuris of states include the opinio iuris of international organizations'). There is simply nothing about any opinio iuris of international organizations. It is all about opinio iuris of States, even though it is recognized in commentary (4) to draft conclusion 4 on general practice, that Io practice "may also count as practice that, when accompanied by acceptance as law (opinio iuris), gives rise or attests to rules of customary international law in the fields in which they operate".

\subsection{Other Draft Conclusions}

The same conclusion must be drawn when analyzing the other draft conclusions, 11 to 16 . Here again the ILC seems to be of two minds: it recognizes the relevance of international organizations, but the question is whether it really takes them seriously. Some conclusions are of a general nature. This is true, for example, of draft conclusion 11 ("Treaties"). The relevance of international organizations is recognized in particular in draft conclusion 12 ("Resolutions of international organizations and intergovernmental conferences"). But then there is draft conclusion 15 , from which it appears that only States, not international organizations, can be persistent objectors.

\section{$2.4 \quad$ The Commentary}

Apart from the draft conclusions, the commentary must be taken into account in order to find out whether the ILC has taken international organizations seriously in its recent work on customary international law.

The commentary does not start very promisingly. In the third general comment the ILC states the following: " $t$ ] he draft conclusions reflect the approach adopted by States, as well as by international courts and tribunals and within international organizations" (emphasis added). This seems to refer to the conduct of States within international organizations. The ILC does not say '... by international organizations', and it is not clear why. If the draft conclusions would state that only the practice of States contributes to the formation, or expression, of rules of customary international law, the 'within formula' would be appropriate. But draft conclusion 4.2 correctly recognizes that the practice of international organizations may also contribute to the formation, or expression, of rules of customary international law. It is not clear why this is not reflected in the third general comment.

In the remainder of the Commentary there are two parts of particular relevance in determining whether or not the ILC has taken international organizations seriously: the commentaries accompanying draft conclusions 4 and 12. Below I will focus primarily on the commentaries to draft conclusion 4, 
as it is here that the ILC offers some dense general observations on the practice of international organizations.

\subsection{What is Practice of International Organizations? The Commentaries to Draft Conclusion 4}

A first comment concerns what is not mentioned: commentaries 3 to 8 are about the practice of international organizations, but they do not refer to the notions of 'practice of the organization' and 'established practice of the organization' at all. The notion of 'practice of the organization' has been used frequently in decisions of the International Court of Justice. Usually it is an additional argument in the reasoning of the Court. After the Court has mentioned a number of arguments in favour of a particular point of view (e.g. international legal personality of the UN (Reparation for Injuries), operational expenses as part of the UN budget (Certain Expenses), or a broad interpretation of Article 12 of the UN Charter (Wall)), the Court adds that its interpretation is 'confirmed' by what it calls 'the practice of the organization'. ${ }^{8}$ In addition, the notion of 'established practice of the organization', is mentioned in the 1975 and 1986 Vienna Conventions, and also in article 2 of the ARIO, as an example of "rules of the organization", next to constituent instruments, resolutions, etc. ${ }^{9}$ The commentaries to draft conclusion 4 do not refer to these two notions at all, even though 'practice of the organization' is at the heart of para. 2 of draft conclusion 4. The Special Rapporteur briefly referred to these two notions in his third report (2015), in which he adopted a restrictive interpretation (saying that they only concern the internal operation of international organizations). ${ }^{10}$ But this did not then lead to a brief analysis in the Commentary which could have provided conceptual clarification. In this context I refer to a useful (and timely) German dissertation by Christopher Peters

8 See further E. Lauterpacht, 'The Development of the Law of International Organizations by the Decisions of International Tribunals' (1976) 152(IV) Recueil des Cours 379.

9 See further the commentaries (17) and (18) to art 2 of the ARIO (Report International Law Commission on its Sixty-Third Session, Un Doc. A/66/10 (3 October 2011), 78) and in particular the second report on responsibility of international organizations, by Special Rapporteur Gaja (Second Report on the Responsibility of International Organizations, UN Doc. A/CN.4/541 (2 April 2004), 8-9).

$10 \quad$ Third Report on Identification of Customary International Law, UN Doc. A/CN.4/682 (27 March 2015), 49-50. 
that is devoted to this important topic. ${ }^{11}$ Peters refers to established practice of an international organization as 'quasi customary law of the organization. ${ }^{12}$ Now, of course, the purpose of mentioning 'practice of international organizations' in the context of the topic of customary international law is only to identify to what extent and how it "contributes to the formation, or expression, of rules of customary international law" (draft conclusion 4.2). But in order to be able to fully identify this, would it not be necessary to have a deeper understanding of this notion, its legal meaning, and how it relates to the sister notions of 'practice of the organization' and 'established practice of the organization'?

My second comment is not about something that is missing in these commentaries, but about the substance of what actually is included in commentaries (3) to (8). Here, again, the ILC seems to be of two minds. On the one hand, it recognizes the autonomous role played by international organizations in the formation of customary international law. It rightly distinguishes between practice of the organization and that of its members. It correctly notes that international organizations "may have their own rights and obligations under international law" (commentary (4)). At the same time, however, the ILC seems to be unnecessarily restrictive, somewhat strained, in describing the role of international organizations. This is so, for example, where the commentary discusses powers of international organizations. The ILC first refers to international organizations having certain "exclusive competences". In this case the practice of international organizations "may be equated" to the practice of States. The Commission refers to the European Union in this context. ${ }^{13}$ But the notion of "exclusive competences" is not used by international organizations in general, it is not even certain whether it is used at all outside the European Union. The ILC does not further elaborate this, which is also noteworthy because the 2011 ARIO (and the commentary) do not refer to it. Furthermore, in commentary (6), where the ILC discusses powers that are not exclusive, it distinguishes between powers "that are functionally equivalent to the powers exercised by States", and powers that are not. It is not clear on what basis these distinctions are made and what they really mean. Nor is clear why "acts of international organizations that are not functionally equivalent to the acts of

11 Christopher Peters, Praxis Internationaler Organisationen-Vertragswandel und völkerrechtlicher Ordnungsrahmen (Springer, 2016).

12 Ibid., 176-181.

13 See further R.A. Wessel, 'Flipping the Question: The Reception of EU Law in the International Legal Order' (2016) Yearbook of European Law 533-561. 
States are unlikely to be relevant practice". In my understanding, powers are attributed to international organizations because States can no longer fully exercise such powers on their own, or because they can do so more efficiently through an international organization. So, in principle, are not acts of international organizations by definition 'functionally equivalent' to those of States? Another example is commentary (8), where the ILC states that "caution is required in assessing the relevance and weight" of the practice of international organizations. Here the ILC seems to find it difficult to simply accept the implications of international organizations as international legal persons, to be distinguished from that of their members. It seems to find it difficult to accept the relevance of the practice of international organizations for the identification of customary international law, where this practice is not in line with that of its members.

\subsection{Resolutions as Acts of International Organizations-the Commentaries to Draft Conclusion 12}

Finally, draft conclusion 12 and the commentaries to it deal with resolutions of international organizations and intergovernmental conferences. Within the confines of this editorial I would like to make one general comment on what the ILC has drafted, as it relates to the very nature of resolutions of international organizations. The ILC almost exclusively seems to regard resolutions as means by which the practice and/or opinio iuris of States can be determined; it does not seem to fully recognize them as acts of the organization, a separate legal person. ${ }^{14}$ That impression is created, first of all, because this draft conclusion equates resolutions of international organizations with resolutions of intergovernmental conferences, even though the two are different: in the case of the former, resolutions emanate, strictly speaking, not from the members but from the organization; in the case of the latter this is not so, because conferences are not separate international legal persons. That impression is further fuelled by draft commentary (3), which states the following: "[a]lthough the resolutions of organs of international organizations are acts of those organs, in the context of the present draft conclusion what matters is that they may reflect the collective expression of the views of States members of such organs". The ILC correctly distinguishes between the organization and its members in this sentence, but it also makes clear it is concentrating

\footnotetext{
14 See also S. Mathias, 'The Work of the International Law Commission on Identification of Customary International Law: A View from the Perspective of the Office of Legal Affairs' (2016) 15 Chinese Journal of International Law 17 (in particular at 25-30).
} 
on the views of the members rather than those of the organization. Why does it not matter that resolutions are also acts of organs of international organizations?

In my view, the ILC should have been more consistent, more realistic, more open-minded and future-oriented in dealing with the role of international organizations in these draft conclusions and the commentary, no matter whether one considers well-known organizations such as the UN, the IMF, NATO and the EU, or less-well known international organizations such as ITER (of which Euratom is a member), CERN, ESA, the Andean Community, aSeAn, the East African Community, the ствто PrepCom, the International Organization of Vine and Wine and the International Commission on Missing Persons.

\section{Beyond the Draft Conclusions: On the Relevance of Customary International Law for International Organizations}

Following these comments, I need to flag a related issue. In my view, it is necessary to look at the topic 'international organizations and customary international law' not in isolation, but also in a more general or holistic way. As mentioned in the introduction, it is increasingly recognized that international organizations are bound by customary international law. Not just "in certain cases", but in general. Of course, many rules of customary international law simply do not apply to international organizations, as they normally have no territory, no territorial waters, no nationals, etc. But in the areas in which powers have been given to international organizations, it is increasingly recognized that these organizations are bound by the relevant rules of customary international law that are applicable in these areas. If this is the case, should international organizations (predominantly having States as their members) not then be in a position to also fully take part in the formation of the relevant customary international law, in the specific fields in which each organization operates? Why should they fully comply with rules of customary international law without being able to fully participate in its development?

In the years to come it may become more necessary to fully recognize that international organizations are bound by international law. During the last two decades, there has been an emphasis on the need for international organizations to be accountable. Articles on the responsibility of international organizations were adopted by the ILC in 2011. As stated in Article 4 of the ARIO: 
[t]here is an internationally wrongful act of an international organization when conduct consisting of an action or omission:

a) is attributable to that organization under international law; and

b) constitutes a breach of an international obligation of that organization. ${ }^{15}$

A considerable amount of research has already been carried out on the first element, in particular relating to whether conduct is attributable to an international organization or to one or more of its Member States. But the second element is somewhat under-researched, even though the preliminary question of what obligations bind international organizations is an important one. To assess whether there is a breach of an international obligation by an international organization, we first need to know by which international obligations international organizations are bound. First, of course, there are treaties, such as the organization's own constitution and treaties to which it is a party, including its host state agreement. In addition, many international organizations have concluded more specific agreements within their fields of competence that may contain obligations for them. However, apart from these treaty obligations there is a gap. There is a gap because, on the one hand, there has been a formidable increase in the activities of international organizations, but on the other hand this does not go hand in hand with a parallel embedding of these activities in the existing international legal order. Of course, there is the Vienna II Convention (1986) as a basis. But international organizations are not parties to major law-making treaties such as human rights conventions and the Geneva Conventions. Moreover, the ongoing saga of the accession of the EU to the ECHR has demonstrated how complex this is.

Therefore, if international organizations are not to carry out their increasing number of activities in limbo, in a vacuum, unbound by law, then customary law is an important source of law to fill this void. But if we agree these activities of international organizations should be governed by the rule of law, then we must also accept that they can contribute in a serious way to the development of customary international law. If they are not taken seriously in the identification of customary international law, why should they take customary international law seriously?

15 See also art 11 of the ARIO: "An act of an international organization does not constitute a breach of an international obligation unless the organization is bound by the obligation in question at the time the act occurs". 
4 Conclusion

The set of draft conclusions adopted at first reading in 2016 is a considerable achievement. These conclusions may provide much needed guidance in practice, whenever an answer must be given to the question of what is, and what is not a rule of customary international law. Nowadays such questions often concern international organizations, as was illustrated in the opening lines of this editorial. The examples given demonstrate that rights and duties derived from customary international law may be important for the successful performance of their functions. It is therefore important that their current role is adequately reflected in the ILC conclusions. International organizations have come of age. This should also be reflected in international law, including customary international law, and in the work of the ILC. In its work on the ARIO, the ILC has fully recognized international organizations as independent entities, to be distinguished from their members. They may commit their own internationally wrongful acts, for which they are themselves responsible. Does the ILC follow the same approach in its more recent work on customary international law? Is it consistent? The ILC has certainly paid attention to the role of international organizations, but my conclusion is that it has not yet taken international organizations sufficiently seriously in its draft conclusions, as adopted at first reading in 2016. Therefore, it is hoped that the ILC will take 'a fresh international organizations look' at its work on this topic in 2018 and will reconsider both the draft conclusions and the commentary. 